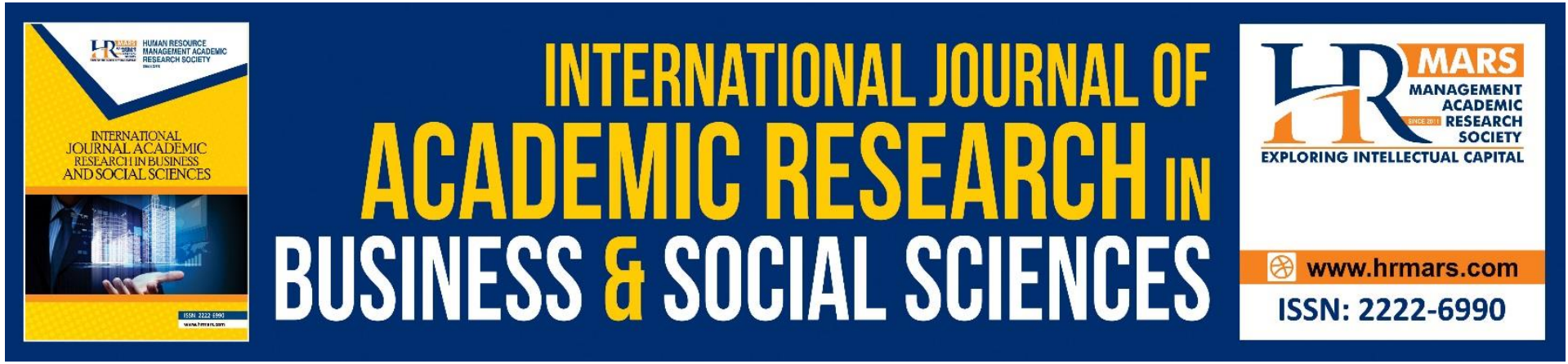

\title{
Analysis of Malay-Language Scholarly Books Distribution From the Perspectives of The Publisher
}

Nurul Fadzlin Mohd Asri, Sharil Nizam Sha'ri, Rohaidah Kamaruddin, Zaitul Azma Zainon Hamzah, Rozita Che Rodi

To Link this Article: http://dx.doi.org/10.6007/IJARBSS/v11-i8/10730

DOI:10.6007/IJARBSS/v11-i8/10730

Received: 09 June 2021, Revised: 28 June 2021, Accepted: 25 July 2021

Published Online: 06 August 2021

In-Text Citation: (Asri et al., 2021)

To Cite this Article: Asri, N. F. M., Sha'ri, S. N., Kamaruddin, R., Hamzah, Z. A. Z., \& Rodi, R. C. (2021). Analysis of Malay-Language Scholarly Books Distribution From the Perspectives of The Publisher. International Journal of Academic Research in Business and Social Sciences, 11(8), 286-294.

Copyright: @ 2021 The Author(s)

Published by Human Resource Management Academic Research Society (www.hrmars.com)

This article is published under the Creative Commons Attribution (CC BY 4.0) license. Anyone may reproduce, distribute, translate and create derivative works of this article (for both commercial and non-commercial purposes), subject to full attribution to the original publication and authors. The full terms of this license may be seen at: http://creativecommons.org/licences/by/4.0/legalcode

Vol. 11, No. 8, 2021, Pg. 286 - 294

Full Terms \& Conditions of access and use can be found at http://hrmars.com/index.php/pages/detail/publication-ethics 


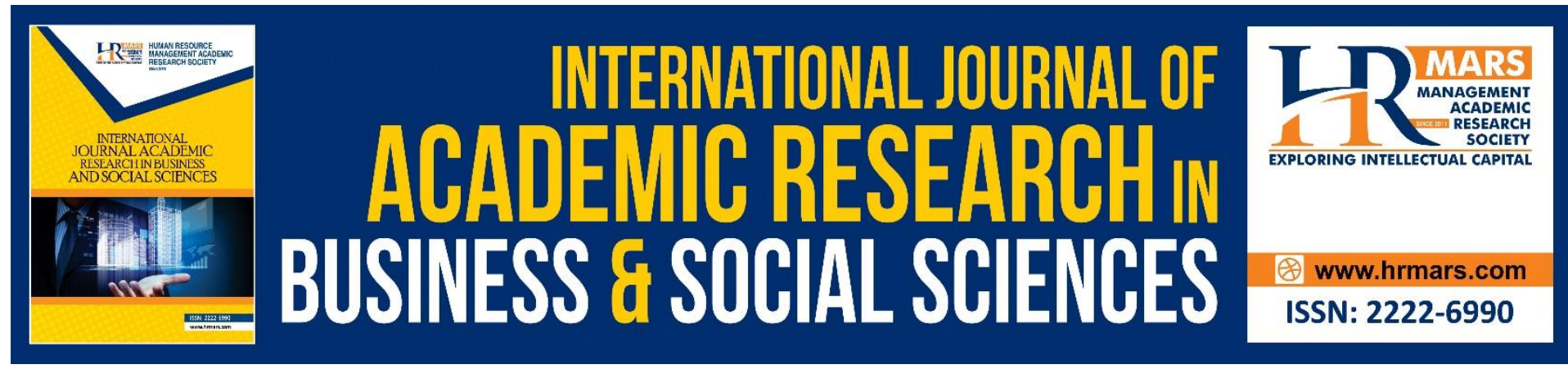

\title{
Analysis of Malay-Language Scholarly Books Distribution From the Perspectives of The Publisher
}

\author{
Nurul Fadzlin Mohd Asri, Sharil Nizam Sha'ri, Rohaidah \\ Kamaruddin, Zaitul Azma Zainon Hamzah, Rozita Che Rodi \\ Department of Malay Language, Faculty of Modern Languages and Communication \\ Universiti Putra Malaysia, 43400 Serdang, Selangor
}

\begin{abstract}
The continuation of publication of scholarly books in Malay language should be maintained as a medium of knowledge dissemination through a written language that can be read by the people of this country. But, the Malay-language scholarly books has received poor reception among the target group. This is so because, the society underestimate the quality of the Malay language in interpreting the diverse disciplines of science. This phenomenon has affected the landscape of Malay-language scholarly book publishing industry in Malaysia. Nevertheless, there are, Malay-language scholarly books that gain recognition, both locally and internationally. This clearly proves that the quality of the book in the publishing process is one of the strategies adopted in promoting the book. Thus, this study aims to identify the Malaylanguage scholarly books published by Universiti Putra Malaysia (UPM Press) and analyze the distribution practices of the selected Malay-language scholarly books by using the principles of marketing by Kotler \& Armstrong (2019). The findings of this study prove that, UPM Press has practiced the principles of marketing as a strategy to distribute their scholarly books since the scholarly books published by the UPM Press do have its own place in the market of Malaysian book industry.
\end{abstract}

Keywords: Sustainability, Practice, Malay Language, Scholarly Books, Public University Press

\section{Introduction}

The publication of Malay-language scholarly book publishing is a process conducted by the publishers in an endeavor of developing a language system that can be used in all branches of scientific disciplines (Omar, 1993). Therefore, this planning should be implemented as best as possible so that the scholarly books will be recognized as a good quality product to be offered in the market (Adnan \& Hashim, 2019a). This is because a good quality product assures the continuity of the book (Kamaludin, 2018).

\section{Problem Statement}

Based on the researcher's analysis and understanding of the focus of the study related to the distribution of scholarly books, there is a research gap in the industry. This is because the previous researchers focused more on problems in term of the effectiveness of book 
distribution in making a profit (Adnan \& Hashim, 2019b). However, very few research have been conducted focusing on the dilemma of fewer number of Malay-language scholarly books being distributed or sold compared to the targeted amount each year (Adnan, 2016).

In relevance to that, the focus of previous studies was on the aspect of language in the scholarly book publishing industry (Asri, 2019a). Still, very few research have been conducted to analyze the quality of Malay-language scholarly books from the perspective of publishers. It is seen as significant because the small number of Malay-language scholarly books being published every year is said to be repeatedly occuring due to the target group been underestimating the quality of the Malay-language scholarly book in interpreting various fields of scientific disciplines (Asri, 2019b).

\section{Objectives}

The objectives of this study are as follows:

1. To identify the Malay-language scholarly book as a product issued by Universiti Putra Malaysia publication (UPM Press).

2. To analyze the Malay-language scholarly book by using the principles of marketing by Kotler \& Armstrong (2010).

\section{Methodology}

This study is a qualitative research in which the researcher obtains the data through text and writing. It is also supported by utterances and interactions heard during the interviews with the marketing officer of the UPM Press. In summary, the researcher searched through the UPM Press catalog to obtain data on the Malay-language scholarly books published in the year 2015, 2016, and 2017. The data were listed one by one in the table forms to see the total number of publications in each year.

Next, the researcher analyzed the distribution practices of the selected Malay-language scholarly books by using the principles of marketing by Kotler and Armstrong (2010a). This analysis is made based on four parts in the book publication structure, which are the cover, the text, the front matter, and the back matter. It aims to examine the scholarly book distribution practices based on principles of marketing. The results of the analysis can conclude that the characteristics of the scholarly book is one of the distribution practices applied by the publisher.

\section{Concept of Products from the Perspective of Publishing Practitioners}

Malay-language scholarly book is one of the products that has been produced by UPM Press. The ability to present a competitive product is essential as an effective marketing strategy. Through the use of high technology and expertise, publishers need to produce good quality scholarly books. However, to have a competitive advantage at the marketing level, the publisher will have to take various initiatives (Charty, 2000).

Basically, the most important thing in the marketing of scholarly books is to follow the current needs, wants, and expectations of the target group which includes language quality, suitability of books according to needs, good binding methods, as well as various attributes of the product should be taken into account as a way to attract the target group (Kotler and Armstrong, 2010b). 


\section{Identification of Malay-language Scholarly Books}

Based on the first objective, the identification of Malay-language scholarly books is focused on the number of the scholarly books published by UPM Press in the year 2015, 2016, and 2017. Thus, Table 1.0, Table 2.0, and Table 3.0 are the lists of the publications of Malaylanguage scholarly books that have been identified through the UPM Press catalog:

Table 1.0: List of UPM Press Publications of Malay-language Scholarly Books in 2015

\begin{tabular}{|c|l|l|}
\hline No & Book Titles & Publication Year \\
\hline 1. & $\begin{array}{l}\text { Balaghah Melayu berdasarkan Balaghah Arab: Satu } \\
\text { Pengenalan dalam Ilmu Bayan }\end{array}$ & 2015 \\
\hline 2. & Hang Tuah Catatan Okinawa (Hard Cover) & $\mathbf{2 0 1 5}$ \\
\hline 3. & Hang Tuah Catatan Okinawa (Soft Cover) & $\mathbf{2 0 1 5}$ \\
\hline 4. & Hassan Ahmad: Wira Bahasa yang Berwibawa & 2015 \\
\hline 5. & Keris Melayu Semenanjung: Suatu Pengenalan & 2015 \\
\hline 6. & Masjid Pasca Model Malaysia & 2015 \\
\hline 7. & Teknik Belajar Membaca \& Menulis Bahasa Thai & 2015 \\
\hline
\end{tabular}

Table 1.0 shows seven (7) title of the Malay-language scholarly books published by the UPM Press. The number of titles is focused on Islamic studies, Malay warriors, and Malay literature. These titles of the Malay-language scholarly books cover various fields of social sciences.

According to UPM Press publication officer Herzadawati, during an interview on January 28, 2019, she said that,

"Scholarly books are a form of product produced by publishers to meet the needs of the target group, especially academics who make the book as a reference material or guide in their academic activities."

Therefore, the special features of a book should be applied as a distribution strategy to produce products that meet the needs of the readers who require the book as reference material. However, according to her, it is the demand and needs of customers that determine the increase in sales revenue (Luhan, 1962).

This is clearly visible as the Malay-language scholarly books published by the UPM Press do have features that can attract attention, can be owned, used and has psychological benefits as well as benefits of academic offered in the market, and can satisfy the needs of the customers (Amjah, 2019a).

Herzadawati, in an interview on May 25, 2019 also explained,

"There are 6 titles that showcase the use of literary language. This can be proven as the title of the book published is an idea and contribution of views by the experts from the field, and the style of language is, of course, based on the type of the field discussed. It is seen as a strategy that is highlighted through the quality of language."

This statement is on par with the report by Hassan (2019) who explained that a good quality product is among the main aspects that consumers evaluate. 
Table 2.0: List of UPM Press Publications of Malay-language Scholarly Books in 2016

\begin{tabular}{|l|l|l|}
\hline No. & Book Titles & Publication Year \\
\hline 1. & $\begin{array}{l}\text { Ciri-Ciri Bahasa Arab Fonetik, Morfologi, \& Sintaksis } \\
\text { Edisi Kedua }\end{array}$ & 2016 \\
\hline 2. & Etimologi Nama Negeri di Malaysia & 2016 \\
\hline 3. & Kaunseling Kerjaya Abad ke-21 & 2016 \\
\hline 4. & Keris Warisan Melayu & 2016 \\
\hline 5. & Kuasai Daya Ingatan Anda & 2016 \\
\hline 6. & Penilaian Program dalam Pendidikan dan Sains Sosial & 2016 \\
\hline 7. & Perumpamaan dalam Al-Quran & 2016 \\
\hline 8. & $\begin{array}{l}\text { Takmilah, Semiotik, Intertekstualiti dalam Karya } \\
\text { Sastera Melayu }\end{array}$ & 2016 \\
\hline
\end{tabular}

Table 2.0 shows the Malay-language scholarly book titles published in 2016 . This amount represents an increase of one (1) title compared to the previous year. This small increase is still seen as positive since the UPM Press still maintains its role to disseminate knowledge to the community.

In the meantime, Amjah (2019b) explained that during the year, the publisher faced shortage of new manuscripts. Even so, the contributions for the Malay-language scholarly books publication and the effective marketing strategy to sell the existing books are continued.

Based on the observation, the Malay-language scholarly book titles published in 2016 are also related to social sciences. However, there is a uniqueness as there are books related to science and also Arabic language written in Malay language to bring better understanding to the reader. The books Kuasai Daya Ingatan Anda and Ciri-ciri Bahasa Arab Fonetik, Morfologi, \& Sintaksis Edisi Kedua are written in Malay Language.

In this regard, Mohd Rusdy Hassan, interviewed on May 5, 2018 said,

"This publication can foster better understanding in reading as the science book is published in Malay language, and it is a strategy that is set by the UPM Press to accept the manuscript and further sell the Malaylanguage scholarly books."

This can be supported with the explanation by Mustafa (2015), choosing different language register accordingly to different social situations means that the community do recognize the varied social situations or levels that exist around them. Thus, their psychology is influenced by the tendency of knowing things that are outside of their field.

Based on the increment, UPM Press appear to have focused more specifically on producing high quality books for readers in the country. For example, the book that has been the focus of the target group and get a high demand such as Hang Tuah: Catatan Okinawa which has been printed more than once (Amjah, 2019c).

According to her, this situation clearly demonstrates that the UPM Press fight for the continuity and survival of Malay language through good quality academic writing strategy. Therefore, the publication of Malay-language scholarly books is a product offered for readers regardless of their background knowledge to prepare themselves with various fields of knowledge disciplines as well as help in developing civilized society. 
"Diverse knowledge disciplines including Islamic principles, culture, philosophy, pedagogy, sociology, dictionaries, Malay writings, aerospace, vocational education, and many more have eventually make the UPM Press become more successful in proving the relevance of adapting Malay language in scholarly books that have its own target reader."

(Amjah, 2019).

Table 3.0: List of UPM Press Publications of Malay-language Scholarly Books in 2017

\begin{tabular}{|c|c|c|}
\hline Bil. & Judul Buku & Tahun Terbitan \\
\hline 1. & Ciri Ciri Bahasa Arab & 2017 \\
\hline 2. & Etimologi Nama Negeri di Malaysia & 2017 \\
\hline 3. & Getah, Tanah \& Pembanggunan Ladang & 2017 \\
\hline 4. & Hang Tuah dari Perspektif Sejarah & 2017 \\
\hline 5. & $\begin{array}{l}\text { Islam dalam Sejarah dan Pemikiran Masyarakat } \\
\text { Peranakan Cina di Melaka }\end{array}$ & 2017 \\
\hline 6. & Kaunseling Perkembangan Kerjaya Abad ke-21 & 2017 \\
\hline 7. & Keris Warisan Melayu & 2017 \\
\hline 8. & Kuasai Daya Ingatan Anda & 2017 \\
\hline 9. & Kota Kuala Kedah Gelanggang Harimau Menerkam & 2017 \\
\hline 10. & Mukjizat Perumpamaan Haiwan dalam Al-Quran & 2017 \\
\hline 11. & $\begin{array}{l}\text { Panduan Guru: Program Khas Integrasi Masalah } \\
\text { Pembelajaran Disleksia KSSR Tahap } 1 \text { bahasa Melayu } \\
\text { \& Dunia Sains dan Teknologi }\end{array}$ & 2017 \\
\hline 12. & Panduan Penulisan Memoir, Autobiografi \& Biografi & 2017 \\
\hline 13. & $\begin{array}{l}\text { Pembelajaran Bahasa Arab dalam Kalangan Warga } \\
\text { Emas: Konsep, Prinsip dan Keperluan }\end{array}$ & 2017 \\
\hline 14. & Penilaian Program dalam Pendidikan \& Sains Sosial & 2017 \\
\hline 15. & $\begin{array}{l}\text { Takmilah, Semiotik, Intertekstualiti dalam Karya } \\
\text { Sastera Melayu }\end{array}$ & 2017 \\
\hline
\end{tabular}

Next, Table 3.0 presents the title of books published in 2017. It is still dominated by the social science topics. The increment of the number of books published indirectly proves that it is the result of the effective marketing strategy practiced by the publisher in producing the Malaylanguage scholarly books.

Based on the increment, UPM Press appear to have focused more specifically on producing high quality books for readers in the country. For example, the book that has been the focus of the target group and get a high demand such as Hang Tuah: Catatan Okinawa which has been printed more than once (Amjah, 2019d).

According to her, this situation clearly demonstrates that the UPM Press fight for the continuity and survival of Malay language through good quality academic writing strategy. Therefore, the publication of Malay-language scholarly books is a product offered for readers regardless of their background knowledge to prepare themselves with various fields of knowledge disciplines as well as help in developing civilized society.

"Diverse knowledge disciplines including Islamic principles, culture, philosophy, pedagogy, sociology, dictionaries, Malay writings, aerospace, vocational education, and many more have eventually make the UPM 
Press become more successful in proving the relevance of adapting Malay language in scholarly books that have its own target reader."

(Amjah, 2019).

In the meantime, three (3) titles of the Malay-language scholarly book published by the UPM Press were identified to be well-received in the book market. The titles are the Hang Tuah Catatan Okinawa, Keris Melayu Semenanjung: Suatu Pengenalan, and Keris Warisan Melayu. Thus, it is proven that the UPM Press gives priority in producing good quality product in certain aspects of publishing to improve the quality of their scholarly books so that good quality products can be offered in the book market (Charty, 2000).

\section{Analysis of Internal Structure of the Selected Malay-language Scholarly Book}

Based on the second objective, Hang Tuah: Catatan Okinawa, is a Malay-language scholarly book which has won the MAPIM-KPT 2015 Award for the category of Popular Scholarly Book Award. Therefore, the analysis on the book is conducted based on four (4) important aspects to prove that this book is a publication of scholarly book that has its own quality. The four (4) aspects analyzed based on the structure of a book according to Gaya Dewan are the cover part, the text part, the front matter part, and the back matter part.

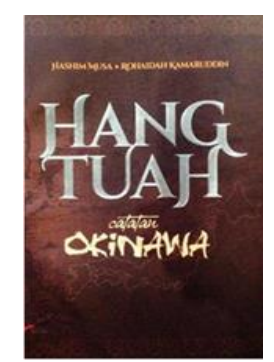

Figure 2.0: Hang Tuah: Catatan Okinawa

\section{Cover}

Figure 2.0 shows the cover of the Malay-language scholarly book that has won the MAPIMKPT 2015 Award for the category of Popular Scholarly Book Award. The victory earned is seen to be correlated with the quality of the book that has been offered to the market. One of the qualities is that the product is a Malay-language scholarly book which can effectively disseminate varied knowledge disciplines. Therefore, the market shows that positive response is gained from the target group.

The design of the book cover features elements of literature and identity of the Malay community through the brown color in the background. The brown color selection as the theme of the cover of this book clearly reflects the nature of the Malays who view the colour of the land is synonymous with the origins of their identity, and it is very close to the characteristics of Hang Tuah, the symbolic Malay warriors that left many traits of heroism in the history of the Malacca Sultanate.

\section{Text}

As for the text section of the Hang Tuah: Catatan Okinawa, the font used is Helvetica Neue Regular in the size of 10/14, and the binding method used is the Perfect Binding. This type of binding is strong enough to maintain the quality and neatness of the book for a long time. 
Furthermore, the Hang Tuah: Catatan Okinawa is a book that has relevance to the history of the Malay warriors, and would eventually be used as a reference in the future.

\section{Front Matter}

In the front matter part, the book presented the list of contents page that consists of 5 chapters. Each chapter has its specific title that begins with Chapter 1 that is Pendahuluan: Watak Hang Tuah dalam Masyarakat Melayu, followed by Chapter 2 that is Bukti Catatan Dokumen Kewujudan Tokoh Utama Barat dan Timur dalam Sejarah, next, Chapter 3 that is Pembuktian Kewujudan Hang Tuah dalam Kerajaan Melayu, while Chapter 4 relates to Dokumen Primer Sumber Asing Tentang Kewujudan Hang Tuah dan Negeri Melaka, and ends with Chapter 5 which is the Conclusion.

The contents of this book feature a total of 28 diagrams and 7 types of color maps that highlight the best interior presentation contained in the book Hang Tuah: Catatan Okinawa. Not to forget, the authors and editors of this book who are skillful in the field of languages have also contributed their editorial skills in the text part of as to ensure the success of this book at the book market level.

\section{Back Matter}

At the back matter part, the book uses abstract graphics, and is completed with a simple and easy-to-understand blurb. It describes the summary and the most important part of the content which dissects the history proving the existence of Hang Tuah, Alexander the Great, Julius Ceaser, and Admiral Zheng He (Cheng Ho). It is also reinforced with appendices that prove that the existence of Hang Tuah is indeed true.

The evidence indicated can be found in Annex I that is Terjemahan Bahasa Melayu Sebahagian daripada Buku Atsushi Kobata \& Mitsugu Matsuda 1969, followed by Annex II that is Salinan Surat-Surat dalam Bahasa Cina daripada Kerajaan Melaka kepada Kerajaan Ryukyu dalam Dokumen Rasmi Rekidai Hoan Kerajaaan Ryukyu, followed by Annex III that is Terjemahan Bahasa Melayu Sebahagian (halaman 89-91) daripada Buku Alfonso Dalboquerque, and finally, Annex IV that is Salinan Halaman 89-91 daripada Buku Alfonso Dalboquerque.

\section{Conclusion}

Overall, based on the analysis of the study, the researcher found that the UPM Press have implemented distribution practices based on the principles of marketing by Kotler \& Armstrong (2010c). Elements of this product marketing principle can be clearly seen based on the internal structure of the selected book that has its own justification. The strategies adopted can help increase the quality of Malay-language scholarly books as the products offered to the target group that serves as a medium for the dissemination of knowledge to the public through the use of the Malay language (Adnan, 2019).

\section{Reference}

\section{Books}

Adnan, H., \& Hashim, R. (2019). Penerbitan dan Pemasaran Buku di Malaysia.

Kuala Lumpur: Penerbit Universiti Malaya.

Adnan, H. (2019). Industri Buku di Malaysia: Isu-Isu dan Cabaran. Kuala

Lumpur: Penerbit Utusan.

Charty, M. C. (2000). Basic Marketing: Europian Edition: A Global Managerial Approach.

New York: Ecco Press. 
Kamaludin, F. (2018). Faktor 4P Mempengaruhi Pemasaran Buku Ilmiah Berbahasa Melayu. Shah Alam: Penerbit Universiti Teknologi Mara.

Kotler, P., \& Armstrong, G. (2010). Kotler on Marketing. London: Pearson.

Luhan, M. C. (1962). The Languages. US: Duke University Press.

Omar, A. H. (1993). Bahasa Malaysia Saintifik. Kuala Lumpur: Dewan Bahasa dan Pustaka.

\section{Journals}

Mustafa, E. (2015). Penggunaan Laman sesawang di Penerbit Universiti Malaya sebagai strategi dalam Pemasaran Penerbitan Ilmiah. Jurnal Pengajian Media Malaysia, 14 (1), 93-105.

Adnan, H. (2016). Masalah-Masalah pemasaran Buku Dewan Bahasa dan Pustaka. Journal of Communication, 7 (4), 23-36.

Asri, F. (2019). Aplikasi 4P dalam Pemasaran Buku Ilmiah Berbahasa Melayu oleh Penerbit Universiti Awam Terpilih. Jurnal Sains Sosial, 6 (1), 1-11.

\section{Interviews}

Hassan, M. R. (Strategi Pemasaran Buku Ilmiah Berbahasa Melayu, May 5, 2019).

Amjah, H. M. (Strategi Pemasaran Buku IImiah dan Hubungan 4P, May 10, 2019). 